\title{
Transatlantica
}

Revue d'études américaines. American Studies Journal

\section{The Boustrophedonic Turns Of Suffering in Faithful And Virtuous Night by Louise Glück}

\section{Marie Olivier}

\section{(2) OpenEdition}

1 Journals

\section{Electronic version}

URL: https://journals.openedition.org/transatlantica/17145

DOI: 10.4000/transatlantica. 17145

ISSN: 1765-2766

\section{Publisher}

Association française d'Etudes Américaines (AFEA)

\section{Electronic reference}

Marie Olivier, "The Boustrophedonic Turns Of Suffering in Faithful And Virtuous Night by Louise Glück", Transatlantica [Online], 1 | 2021, Online since 01 July 2021, connection on 03 February 2023. URL: http://journals.openedition.org/transatlantica/17145; DOI: https://doi.org/10.4000/transatlantica 17145

This text was automatically generated on 3 February 2023.

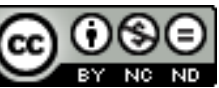

Creative Commons - Attribution-NonCommercial-NoDerivatives 4.0 International - CC BY-NC-ND 4.0 https://creativecommons.org/licenses/by-nc-nd/4.0/ 


\section{The Boustrophedonic Turns of Suffering in Faithful And Virtuous Night by Louise Glück}

\section{Marie Olivier}

1 In her latest collection, Faithful and Virtuous Night, published in 2014, Louise Glück explores a new form in her work where prose poems alternate with free verse. This dual characteristic is in keeping with the poet's gradual swerving toward a more narrative poetics. As Peter Campion puts it,

no one could accuse this poet of relaxing into the role of the senior laureate reproducing a signature style. Reading these poems, one feels that all the resources Glück has developed up until now have been brought to bear, and yet, even more impressively, that she has demanded of herself new and surprising methods. (Campion, 2014)

Recipient of the Nobel Prize in literature in 2020, Louise Glück is one of the few American contemporary poets whose voice remains unmistakable while offering poetical and aesthetic variations in each of her new collections. Indeed, Glück's writing has endlessly been evolving throughout the years: Averno (2006) already explored longer poems (such as "October" or the Persephone poems for instance), and A Village Life (2009) definitely marked a turn in style, depicting the lives of different speakers in one same village, where time manages to slowly unfold. Faithful and Virtuous Night goes even further in the enquiry of lineation through an alternation of free verse and prose poems.

Both kinds dramatize an oscillation between the time of the lyric, one she refers to as "static/rhapsodic" (Glück, 1997 41), and that of the narrative, which takes the reader through time and space, through "transformation and re-creation" (41). For the first time, and so blatantly in the poet's work, a story develops throughout the whole collection in the past tense, and with a recurring and fictional persona, who is not autobiographical, legendary or mythological. Formally, such inclination towards the narrative also implies an oscillation between line and sentence, a difference which Robert Hass, a fellow Poet Laureate, explains in A Little Book on Form. According to him, 
"the sentence is being, enjambment is excess of being, or being in process, reaching toward itself" (Hass 11).

3 Glück's poetics gestures toward the nuance Hass articulates through the notion of enjambment. It inhabits the oscillation between "being-in-process" and "self-as-aprocess." This oscillation in the poetic gesture incarnates the dynamic of the boustrophedon that helps to construe verse in terms of continuity rather than of rupture. I do not use "boustrophedon" literally, but in the metaphorical sense of the term, which relates it to the definition of verse itself, or versura, as Agamben recalls in Idea of Prose: "the Latin word that indicates the place (and the moment) where the plough turned round at the end of a furrow. It is from the term versus (furrow) that the English word verse derives (turn)" (Agamben 40). ${ }^{1}$ The boustrophedon apparently goes against the very phrasing of "line break," since it almost literally marks the continuous flow of the sentence while retracing it back, revealing a backward motion in the writing process. The bidirectional gesture of the boustrophedon is therefore rooted in verse itself, and in Glück's poetry, it is not visual. However, the term captures the inherent dynamism of the poetic gesture in Faithful and Virtuous Night: a writing in the past tense, which always attempts to go back on what it says, desperately trying to return on its steps while gushing forward on the page. In that way, the boustrophedonic turns of Faithful And Virtuous Night translate as a wandering and wondering poetics, which always reflects and looks back on itself, on its language and possibilities.

4 This essay focuses on the analysis of Glück's poems in verse, and purports to better understand how Glück's chiastic poetics, constantly torn between lyrical urgency and stark reserve, revisits the very notion of pathetic fallacy while presenting a vision of the world that corresponds to Hass's personal definition of enjambment as "excess and instability and movement and change."

\section{Chasm and Chiasmus}

5 As Jonathan Culler brings back to mind in his Theory of The Lyric, "the relative rarity of lyrics in the past tense, though a topic seldom discussed, is not hard to understand: the past tense is a narrative tense and provokes the desire to know what happens next." (Culler, 2015 277) Indeed, narrativity, as well as fictionality in American contemporary poetry are seldom encountered, and with her latest collection, Glück did surprise her readers and critics. Most poems in Faithful and Virtuous Night are in the past tense, and the story of the fictional persona as imagined by Glück structures and gives a backbone to the collection. In numerous poems the reader follows the story of a boy who loses his parents in a car accident. He and his brother move in with their aunt. Later in life he becomes a painter, and grows old. The use of the past tense helps propel the desperate and yet vital energy of Faithful and Virtuous Night, thus partaking of its poetic momentum. Faithful and Virtuous Night is fraught with mourning and experiences of loss through speakers that are either neutral, fictional, or more rarely (as in "Visitors from abroad"), clearly inspired by the poet's life. The collection sheds light on a fragmented and broken human experience. To quote Dan Chiasson, it stages "the knightly faithfulness of the night-". Even though its title evokes a nocturnal atmosphere, the collection is both vesperal and filled with a luminous radiance. The poems are infused with some sort of desperate vitality that does not come across through a fragmented 
syntax and unduly short run-on lines, but through verse that recalls a "middle term" between prose and poetry, which Agamben mentions in Idea of Prose:

The versura, the turning-point which displays itself as enjambement, though unspoken-of in treatises on metrics, constitutes the core of verse. It is an ambiguous gesture, that turns in two opposed directions at once: backwards (versus), and forwards (pro-versa). This hanging-back, this sublime hesitation between meaning and sound is the poetic inheritance with which thought must come to terms. In order to take up the legacy, Plato rejected the transmitted forms of writing, and fixed his gaze on that idea of language, which according to the testimony of Aristotle, was for him neither poetry nor prose, but their middle term (Agamben 41).

Glück explores a middle-term of the same Platonic sort, ${ }^{2}$ which simultaneously pushes and pulls the poem in two opposite directions. It thereby formally enacts the chasm already present in the poems' suffering and mourning personae. This coincides with what I would call a Janusian dynamism, as the process of enjambment synchronously propels verse backward and forward. The reluctance Agamben perceives in the process of enjambment finds an echo in the chiasmus that Glück's writing unfolds between the world and the different speakers in Faithful and Virtuous Night. The lyrical instance becomes the very crux between interiority and exteriority, between intimacy and the outer world, as one can see in "Visitors from Abroad." In this poem, the speaker is given a feminine gender and draws on autobiographical elements. During a night of insomnia, the speaker keeps hearing the telephone ring, and ends up thinking it may be the doorbell. She opens the door and has a vision of her parents, who are now dead, standing in the cold. ${ }^{3}$ The poem is composed of four parts. In the last stanza of the first part, the enjambments mark a regular scansion in each run-on line, with an almost equal number of feet in each line, thus imitating the regular ringing of the phone:

the phone rang, it rang and rang

as though the world needed me,

though really it was the reverse.

(Glück, 2014 22, 1. 5-7)

The quasi-anaphoric repetition "as though" / "though" marks an evolution ranging from illusion to blatant contradiction ("though really it was the reverse"), which the ringing of the phone signals with a diligent constancy. Moreover, the repetition of "though" / "as though" enhances the sharp irony of the poem. The perfect block of these visually equal lines strives to contain a hiatus between the first-person and the outside that seems to be gaping in a paradoxically empty space, blank and white like the streets under the snow: "The street was white again, /all the bushes covered with heavy snow" (26-27). But in the first part of the poem the speaker does not pick up the phone before two stanzas have been completed, and when she does, nobody is on the line:

When I picked it up, the line was dead.

Or was the phone working and the caller dead?

Or was it not the phone, but the door perhaps?

(Glück, 2014 22, l. 12-14)

Contrary to the excerpt above quoted, the line breaks shape end-stopped lines-more particularly, two questions based on the repetition of the same anaphoric structure ("or was / or was...") which not only enhances the pun on "dead" but more generally, the dark comical aspect of the situation, as the speaker tries to explain the absence of addressee. This also puts forward the elegiac tone of the poem, and uncovers the apostrophe as one of the lyric's idiosyncrasies-that the first-person always addresses 
the absent, and consequently, that the interchange suggested in this poem ("though really it was the reverse") not only fails, but also misses the point.

7 In this poem as in many others in the collection, chasm and chiasmus converge: as the speaker acknowledges her "need" of the world, the "call" that is formulated between the lines and in the vertical parallelism of these two questions is not "the world" calling-as the illusion conveyed by the conjunction "as though" makes explicit. The addressee of the call turns out to be the caller himself (through the opposition "though"): it is the world, and not the first-person, that fails to answer. In this poem, the apostrophe apophatically inscribes itself in the concave absence of the addressee, in a deathlike and telling silence, which can only find an echo in the "dead line" as well as the speaker's powerlessness and mutism.

\section{Now and the "Afterwo/ard"}

As its title indicates, the poem "Afterword" can be read as a textual après-coup, and comes in the interstice between narrative and lyric. Following Jonathan Culler's hypothesis, "if narrative is about what happens next, lyric is about what happens now -" (Culler 202), the poem explores the now of the next, but also how senses are numbed by pain, how the perception of the world can be anaesthetized and artistic expression silenced by suffering. In this poem, the speaker is the fictional boy who lost his parents. The figure of the tree is presented as a singular entity, definite and absolute, since it is "the tree that confronted [the speaker's] parents" and caused their deaths in a car accident. Through the vertical figure of the tree, here again, chiasmus and chasm collide. Both point to the very core of the lyrical self, the exact center of the crux as well as the absolute void, "the void of myself," where, paradoxically, everything seems to stop, as in the following stanzas of "Afterword":

Chaos was what I saw.

My brush froze-I could not paint it.

Darkness, silence. That was the feeling.

What did we call it then?

A "crisis of vision" corresponding, I believed,

To the tree that confronted my parents.

(Glück, 2014 30, 1. 21-26)

9 As the first line indicates, "chaos" seems to be what the speaker sees, while the "darkness" and the "silence" he experiences form a chiasmus that intertwines the outside with the inner world, but also language and pictorial language through the blank space of the stanza break. However, and as Agamben reminds us, "where language stops is not where the unsayable occurs, but rather where the matter of words begins" (Agamben 37). In "Afterword," the "matter of words" seems to come to the artist afterward, once the writing has been accomplished ("Reading what I have just written" is the first line of the poem). It thus corresponds to "a crisis of vision"'( in quotation marks) and comes as an answer to the question "what did we call it then?". The articulation of words such as "darkness" and "silence" sound like vain formulations of the artist's feelings who "could not paint it," but desperately tries to "call it." The crisis of vision refers to a dissonance between words and image, the plurality of the former and the singularity of the latter: "corresponding, I believe, / to the tree that confronted my parents." The run-on line gives time for thought and analysis, and allows a correspondence, if not a conflation, to occur between "chaos," 
"darkness" and "silence." The "afterword" is first being deferred through the enjambment, and then, throughout the long poem unfolding across twenty-five stanzas and almost four pages. The tree is supposed to embody a "crisis of vision," and consequently, one that may not stand the integrity of a linear sentence, but rather needs the verticality of run-on lines as well as the juxtaposition of languages-both verbal (through the attempt at "calling") and nominal (through the image of the tree).

At first reading, nature may sometimes look like a milieu where the poetic persona can project and deploy his or her feelings, emotions and thoughts. These projections are always perceived and shaped by vertical or horizontal limits drawn by natural elements, as for instance in the poem "The Past":

Small light in the sky appearing

suddenly between

two pine boughs, their fine needles

now etched onto the radiant surface

and above this

high, feathery heaven-

(Glück, 2014 7, 1. 1-6)

By and large, the collection explores the figure of the tree as a framing device. Here, the trees become a structure that delineates nothingness and questions the relationship between the speaker and the world, but also the lack of coincidence between the world and language.

Quite interestingly, Louise Glück's lyricism deconstructs the coincidence between the now of discourse and the now of writing involved and metaphorized in an etching process that has already taken place. The "etching" of the fine needles onto the radiant surface of the sky is presented as something that has already been done but that is also already lost: the fine engraving on the "radiant surface" of the sky is a process that originates at the very moment of its utterance, but which has already vanished in the chasm of the stanza break, as well as in the chiasmus between the now of the writing and the now of the speech-act.

In these lines the light pierces through the canvas of the sky and creates an interstitial fissure, an aesthetic scar ("now etched onto the radiant surface"), which only appears two lines further, at the end of line 6 , typographically embodied by the dash. The verb "etched" assumes a mode of engraving, of inscription; as a past participle, it turns the "now" of the poem, the time of enunciation, into an après-coup. It is not the process of inscription that is presented in the poem but its result, "now etched," which is separated from its source ("their fine needles") by a stanza break. The past participle stands in opposition to the "appearing" of the small light in the sky, an active -ing form. The stanza break may be construed as a blank space, but also as a partition between the object and the action (etching). As a partition, it differentiates the object from the action, but as a blank space, the stanza break may also be visually construed as a white sheet on which the fine needles are both subject and object, etching themselves "onto the radiant surface" of the page. The past participle and the stanza break position the lyrical instance in an après-coup which, as a consequence, utterly alienates the first-person from the creative process. The traditional dialogical and symmetrical structure of the lyrical apostrophe is therefore misshapen by suffering itself: speech and poetic discourse are thrown out across the stanza break into an unsatisfactory "now" (1. 4). The object of desire, the presence of the beloved remains remote. 


\section{The Swaying Rhythm of Nothingness}

explains in "Apostrophe."

The tension between the narrative and the apostrophic can be seen as the generative force behind a whole series of lyrics. [. . .] Apostrophes displace this irreversible structure by removing the opposition between presence and absence from empirical time and locating it in a discursive time. The temporal movement from A to B, internalized by apostrophe, becomes a reversible alternation between A' and B': a play of presence and absence governed not by time but by poetic power. (Culler, 2001 165-166)

Through a swaying rhythm consisting in the alternation between quatrains, tercets, couplets and the use of one single line (1. 18), "The Past" disturbs linear temporality, and presents the sinuous turns of a poem that follow the wind and the smell of the white pine through the trees. The rhythm of the following lines conveys a quiet atmosphere, enhances the elegiac tone and upsets the lyrical symmetry of enunciation between the speaker and the world (1. 7-23):

Smell the air. That is the smell of the white pine, most intense when the wind blows through it

and the sound it makes equally strange,

like the sound of the wind in a movie-

shadows moving. The ropes

making the sound they make. What you hear now

will be the sound of the nightingale, chordata,

the male bird courting the female-

The ropes shift. The hammock

sways in the wind, tied

firmly between two pine trees.

Smell the air. That is the smell of the white pine.

It is my mother's voice you hear

or is it only the sound the trees make

when the air passes through them

because what sound would it make, passing through nothing?

(Glück, 2014 7, 1. 7-23)

Almost invisibly and quite unremarkably, the poem stages a perceptual inversion that reveals the overarching chiastic structure of the poem. The syntactic inversion between the affirmative and the interrogative clause, "it is" / "is it," in two run-on lines, questions the personification of the wind. It also creates a structural vacuum in which the poetic voice finds itself engulfed to the point of annihilation. Graphically provoked on the page by the stanza break, the blank space embraces the meaning of the following stanza, which endeavors to offer an explanation for, or a resolution to, the feeling of doubt and the relative approximation expressed in the above quoted lines: "because what sound would it make, / passing through nothing?"

From the thick embodiment of the italics in the single line ("Smell the air. That is the smell of the white pine" 1. 18), the mother's voice has progressively weakened, first by being literally questioned before eventually becoming, not nothing or a nothing, but nothingness itself. As the question asks, "what sound would it make / passing through nothing," pointing to the absence of borders as the air and sound are unchanneled in the atmospheric milieu, the voice of the persona's mother blowing through the bare 
trees is negated at the very moment of its emerging into the world through the line break, and before eventually disappearing in the void of the stanza break. The mother's voice is designated by its spectral quality, through its simultaneous presence and absence. By turning it into a radical void, the poetic voice echoes the vacuity within, at the very heart of his being

[...] what I saw, as I told my aunt, was less a factual account of the world than a vision of its transformation subsequent to passage through the void of myself. (Glück, 2014 16, l. 190-193)

The lyrical instance is introduced as the very crux of the chiasmus where the outside and the inside meet, collide and converge. Yet, it is also presented as the cleft located deep within the self: it is simultaneously the subject of discourse and its absence, its deficiency. As Roland Barthes explains in A Lover's Discourse, suffering is one defining feature of the "subject":

This singular reversal may perhaps proceed from the fact that for us the subject, since Christianity, is the one who suffers: where there is a wound, there is a subject: die Wunde! die Wunde! says Parsifal, thereby becoming himself; and the deeper the wound, at the body's center (at the "heart"), the more the subject becomes a subject: for the subject is intimacy ("The wound ... is of a frightful intimacy"). Such is love's wound: a radical chasm (at the "roots" of being), which cannot be closed, and out of which the subject drains, constituting himself as a subject in this very draining. (Barthes 188)

Out of this radical void ("void of myself") the lyrical subject "drains," to use Barthes's own term, as in the poem "Afterword" where the first person is simultaneously exhausted and embodied in a fluid Heraclitean self:

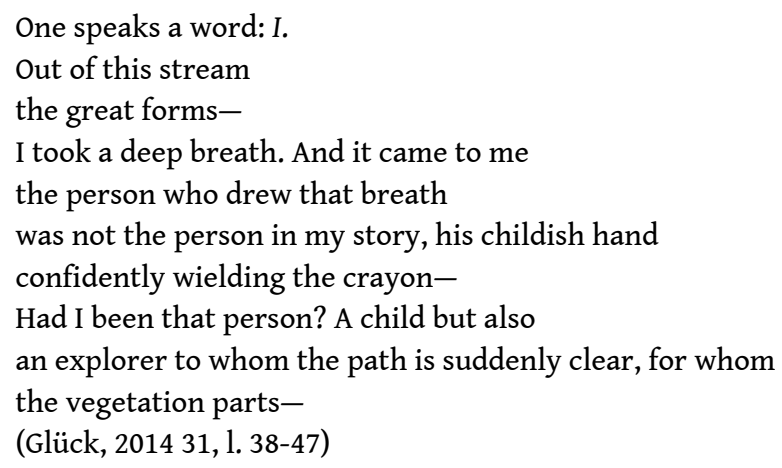

From child to explorer, the writing has allowed the bridging of a gap, a spanning across that has become the fantastic adventure-in other words, that of poetry. The rhythm sounds natural since the sentence is not broken by any line or stanza break, and each new line gives due importance to the words that are most semantically charged. The breathing of the artist is here presented as being both a physical chasm and a corporeal chiasmus. Engendered out of this "deep breath," the written subject comes to concretion as an artist. This also implies that the self has automatically metamorphosed and deviated entirely from its creator once it has been written or drawn on the page: "the person who drew that breath" is not the same as the one who "wielded" the crayon. Between the inhaling and exhaling, between the breathing and the writing, the line break forms: not only an interstice, but also a spatial and temporal boustrophedonic turn, "the place and the moment where the plough turned round at the end of a furrow" to quote Agamben once again (Agamben 40); the shape of a crux 
through which the self is distorted and disfigured, to the extent of being almost negated through the same dashes that had enabled its coming into existence.

\section{The Reforming "I"}

19 The first line of the tercet ("One speaks a word: I") unhinges-and even tears away-the lyrical instance from its personal stem, partaking of the Rimbaldian "je est un autre." The first person is denied its grammatical nature of personal pronoun and becomes "a word." By and large, this participates in the hegemonic unity of the first-person subject observed in Glück's poetics. However, the sentence "One speaks a word: I" does not exceed the bounds of the line (the line starts with an upper case and ends with a period). Towering above the rest of the poem, it seems to concentrate in its five monosyllabic words the two following run-on lines, flowing like a stream: "out of this stream/the great forms-" (1. 40-41). They also hold the paradoxical promise of some boundless entity coming to concretion, tearing itself out of the line thanks to the final dash, which graphically points out of the stanza. It is as if the poem was "reaching toward itself," to borrow Hass's phrasing, through the enjambments of the tercet, as if the horizontal dash was recreating, reforming the vertical "I" on the page, stretching the line to cross out the silence of the stanza break, and eventually gesturing toward yet another "I" across the stanza break at the initial of the next stanza.

Besides, each stanza ends with a dash: all of them differ in meaning, and yet, they are always endowed with the same performative function. Each one of these dashes $(1.40 ; 1$. $44 ; 1.47)$ is the trace of an identical graphic impulse to enact and imitate the semantic content of the preceding lines: the dash following "confidently wielding the crayon-" (1. 40) performs the tracing gesture of the arm before the speaker wonders "Had I been that person?" after the stanza break, making the rift in the lyrical subject even more blatant. In the same way, the dash following the lines "an explorer to whom the path is suddenly clear, for whom/the vegetation parts-" (43-44) rips out the space of the stanza break to make way for the imaginary projection of the speaker: the explorer. However, the typographical gesture is not merely imitative: if the dash marks the trace of the writing process, the latter happens to be also erased in the blackness of its ink. Not unlike the poem "The Past," and its "needles etched onto the radiant surface," "Afterword" and its dashes present the stanza as an incohesive space, one that cannot conclusively find closure in language. Language is helpless to translate the "great forms"-which then could be construed as a noun and as a verb.

The traditional lyrical subject is here turned into an impersonal pronoun ("one"), and the speaker seems to be utterly dissociated from the first person, while in "Visitors from Abroad," the I becomes the second person: "every time I say 'I,' it refers to you" (Glück, 2014 23, 1. 33). ${ }^{4}$ As in any lyric, the first-person incarnates and voices the endlessly absent addressee, but also the other, pictured as visions of her unconscious.

These lines come as an echo, an afterthought to the story of "Faithful and Virtuous Night," a poem preceding "Afterword" and whose first stanza reads:

My story begins very simply: I could speak and I was happy.

Or: I could speak, thus I was happy.

Or: I was happy, thus speaking.

I was like a bright light passing through a dark room.

(Glück, 2014 8, 1. 1-4) 
Undecidability is developed through the chiasmus in the second and third end-stopped lines, which interweaves the capacity to speak with the feeling of happiness, coming to the persona as a sudden surprise. The colon following the conjunction "Or" turns the two chiastic assertions into different hypothetical versions of that first affirmation, supposedly taken for granted: "my story begins very simply." The sense of narrative is here twisted from the outset. The questioning of the causal link ("thus") between the speaking process and the happiness of the speaker not only confounds cause and effect, but also posits the starting point of the narrative of the story-and therefore, the ambitus of the poem-as an afterthought based on an indecision between feeling and writing. The writing process along with the poetic instance undergo a chiastic transformation. Besides, while emotion moves the writing forward, the writing moves emotion forward: "I was a bright light passing through a dark room."

\section{A Faithful and Virtuous [k]night}

In the poem "An Adventure," the speaker bids adieu to "those amorous adventures" and to poetry in a long six-part narrative poem that, as Agamben might say, "hints at a passage of prose with the very gesture that attests its own versatility" (Agamben 40).

But these farewells, I said, are the way of things.

And once more, I alluded to the vast territory

opening to us with each valediction. And with that phrase I became

a glorious knight riding into the setting sun, and my heart

became the steed underneath me.

[...]

As we had all been flesh together,

Now we were mist.

As we had been before objects without shadows,

Now we were substance without form, like evaporated chemicals.

Neigh, neigh, said my heart,

Or perhaps, nay, nay-it was hard to know.

(Glück, 2014 5, 1. 13-17; 1. 35-40)

Although this almost dreamlike narrative forms and informs the poem, Glück's poetics insists on the intransitivity of its writing process, and holds back its meaning in a parabolic way. These lines seem to stage a reluctance to move either forward or backward, what Agamben called a "hanging-back, this sublime hesitation between meaning and sound," (Agamben 41) palpable in the polysemic homophone "neigh" / "nay." The humorous undecidability thus generated between the active and the passive form ironically interlaces the cry of the animal ("neigh, neigh") with the cry of the speaker's heart. This engenders a swaying motion, even a confusion between horse and rider, an indistinction which the other preceding run-on lines had heightened into an inversion: "And with that phrase I became/a glorious knight riding into the setting sun, and my heart/became the steed underneath me."

The sound of the refusal "nay, nay" echoes the pun on "dead" in "Visitors from abroad" and also points to another homophonic pair, "night" and "knight," which appears in another poem, "Faithful and Virtuous Night":

At the time of which I'm speaking,

my brother was reading a book he called

the faithful and virtuous night.

Was this the night in which he read, in which I lay awake? 
No-it was a night long ago, a lake of darkness in which

a stone appeared, and on the stone

a sword growing.

(Glück, 2014 9, 1. 26-32)

Not unlike in "An Adventure," the neighing of the horse becomes negation of desire and self-negation, the confusion between "night" and "knight" makes the hero and its milieu coincide in a chiasmus enhanced by the alliteration in $/ \mathrm{n} /$ and $/ \mathrm{y} /$. The "knight riding into the setting sun" here becomes one with the night, thus embracing the void of his own self, the emptiness of heart that the lyrical subject feels.

Glück's poetics oscillate between a chiastic and a cyclical structure where any attempt to return to one original point ineluctably fails. The poems relentlessly stage different modalities of return to the roundness of the mother's body, that is, according to Freud, "the only place of which one can say with so much certainty that one has already been there." ${ }^{\prime}$ The desire to return to a safe harbor recurs throughout the whole collection, as in the poem "A Sharply Worded Silence," which has a longer breath, and is based even more blatantly on a more narrative form:

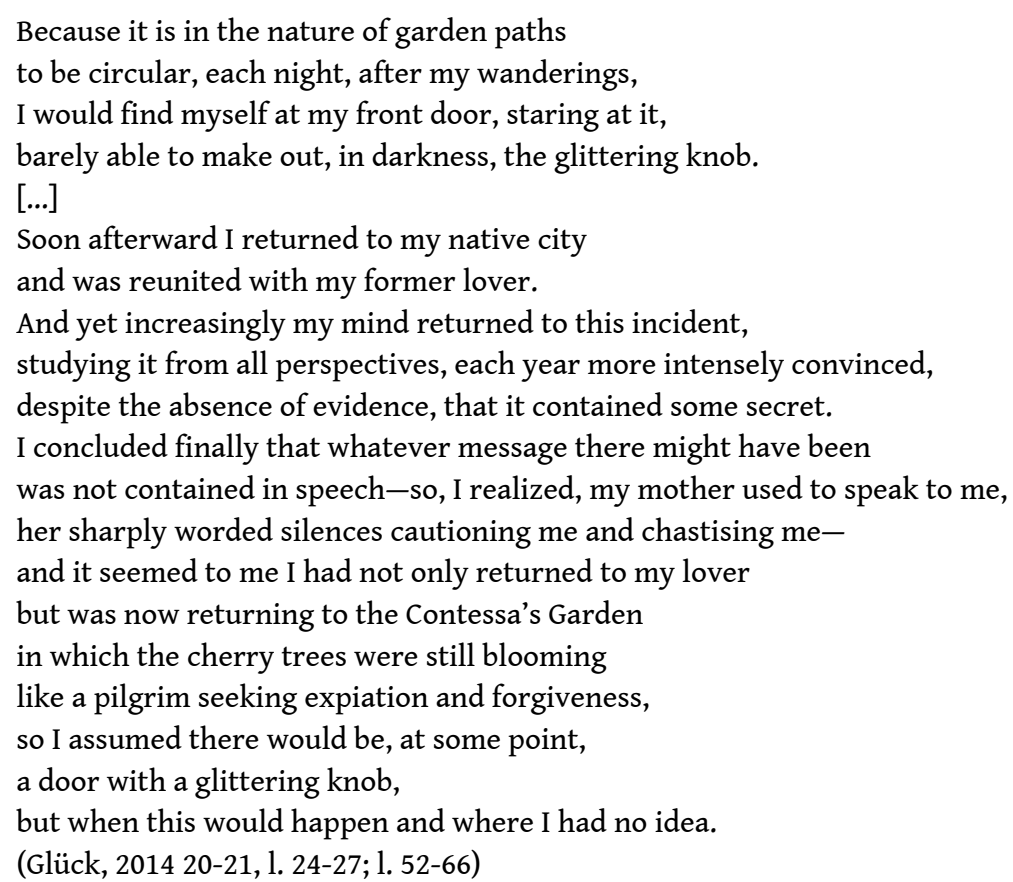

27 The persona keeps coming back to the same garden, ending in front of the same "glittering knob," before eventually returning to his "native city" and being reunited with a "former lover." Yet, the poem hints at incompletion: there is a secret that cannot be uttered, that evades and shuns language. As the mother's "sharply worded silences" are far more telling than any formulated reproach or blame, the "music coming from the trees" and the silences of the garden the persona experiences in the park are more significant and pregnant with meaning than any other kind of discourse. Even in this poem where a story is supposed to be told through long and expansive lines, Glück's lyrical commitment remains to that something "not contained in speech," located at the crux between the individual and the world, locked in "some secret" that constantly evades language, and is evidence of the Heideggerian notion that it is never "I" that speaks, but language. 


\section{The Ball and Dizziness}

her poetic personae and the world exposed, wide open, like a wound. In "Cornwall," the latter takes the shape of a "fissure in a dirt road" $(28,32)$ and then, becomes "an abyss shaped like a tree, a black hole/expanding in the dirt" (35-36)-the same fatal tree which had stopped the persona's parents. Like the abyssal hole expanding in the dirt, the roundness of the lyric apostrophe persists in the collection, but it is not to be found under its traditional and initial form, as a majestic round letter towering above the poem. However, its roundness recurs throughout the whole collection, through the circular shape of stories, of figures believing they have come back to the same point, like the boy in "Faithful and Virtuous Night" shuffling through his First Reader:

On page three, a dog appeared.

On page five, there was a ball-one of the children

threw it higher than seemed possible, whereupon

the dog floated into the sky to join the ball.

That seemed to be the story.

I turned the pages. When I was finished

I resumed turning, so the story took on a circular shape,

like the zodiac. It made me dizzy. The yellow ball

seemed promiscuous, equally

at home in the child's hand and the dog's mouth-

(Glück, 2014 11, l. 78-87)

The disconcerting image of the ball "equally at home in the child's hand and the dog's mouth" calls to and disturbs the reader's senses-physical as well as olfactory-while it also evidences the mobility and the instability of language, the illusion of referentiality. Once in the air, a word never comes back the same, it is instantly deformed, and transformed, thrown out of its initial trajectory through the enjambments, like the ball in "Cornwall":

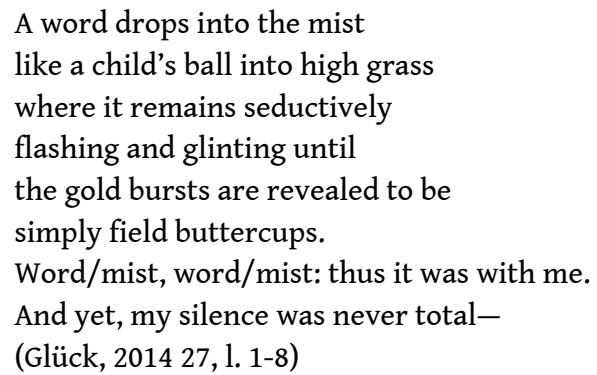

The word that comes to the speaker at a moment of crisis, and which corresponds to a time of silence, is not unlike the transient and fugacious "small light in the sky appearing / suddenly between / two fine boughs" in the poem "The Past" (7, 1. 1-3). The 
ball is here thrown on the ground and remains hidden in the high grass, whereas in "Faithful and Virtuous Night," the ball is flung into the sky: always in motion, it is an object of exchange whose erratic character is enhanced through the alternation "word/ mist, word/mist." The "flashing and glinting" object in the high grass is presented as a vision caught in the alternative opening and shutting motion of a camera's lens: "word/mist, word/mist." Not only does the line designate the fluctuations of an artist's inspiration, but also the false relationship existing between language and the world: "a word drops into the mist." The very materiality of the word seduces whoever wishes to master and own it, but language, despite its mobility and its being an object of trade, remains unattainable, hidden in the high grass, as its visual place hints at-after the stanza break, and in the same line rather than in an alternation on two different lines. Despite the oscillation between the precise word and the vagueness of the haze, the repetition "word/mist, word/mist" marks the vacillations of a writing that constantly challenges language and questions qualification or definition.

While the speaker is seduced by the language he uses, he also remains fooled by it: in spite of all his endeavors, the poet or the artist can never make the balance right between language and the world. The battle is always already lost, and it is not the mission of literature to make it right. On the contrary, the mission of literature by and large, and of poetry more precisely, is to make such relationship so slant as to throw language off balance, to make the reader "dizzy," not unlike the speaker/reader in "Faithful and Virtuous Night" (85). The experience of dizziness, here presented as a child discovering language and learning how to read, how to decipher signs, parallels the experience of the same child throwing a ball and losing it in high grass. Dizziness grounds itself here in an "experience of nothingness," such as Philippe LacoueLabarthe formulated it in his famous study of Celan's poems-the "pure suspension of occurrence: a caesura or a syncope" (Lacoue-Labarthe 19).

The poems in Glück's latest collection become the space where this poetic reluctance engendered by the enjambment allows the possibility for communication, for some interchange with the world, ? to say whatever needs to be said. Yet, at the same time, her writing organizes and structures itself around the failure of such communication, and for it never to be said, as in the poem "Visitors from Abroad." Far from corresponding to what Marjorie Perloff called the linear fallacy in a 1981 essay, Glück's structure of lineation is effective as it creates a perfect lyrical Kairos-the time when it is time-through a poetics that knows when to "turn," turn the line, turn the page in its lengthier aesthetics. Yet, her writing keeps coming back on itself, without ever losing sight of tomorrow, or of the poetic urgency of a now, as one can see in "Midnight":

I held my brother's hand.

We watched the monuments succeeding one another

always in the same order

so that we moved into the future

while experiencing perpetual recurrences.

The boat traveled up the river and then back again.

It moved through time and then

through a reversal of time, though our direction

was forward always, the prow continuously

breaking a path in the water.

(Glück, 2014 35, 1. 44-48)

Like the prow breaking a path in the water, Glück's lines keep moving forward on the page while the iterability of such "perpetual recurrences" impels analepses and 
therefore, demonstrates a poetic vigor that simultaneously explores the versus and the pro-versa.

The poet seizes the freedom there is in "free verse" to take the time precisely not to say, thus diligently deferring the appropriate time. For instance, in "Afterword," or in "A Sharply Worded Silence," the secret is never uttered thanks to a "suspension of occurrence." Even though her poems never let go of "the being-present of the present," of the urgency that inhabits the now of the lyric, Glück's poetics is animated by a Janusian dynamics facing forward and backward. As one can read in the poem "Faithful and Virtuous Night," it seems that the speaker tries to face the pain of looking both ways, and ends up shunning the following paradigm: "It had occurred to me that all human beings are divided/into those who wish to move forward/and those who wish to go back." (Glück, 2014 15, l. 165-167). The poet, like a certain famous scrivener, "would prefer not to" pick a side. In her poems the lyrical instance looks like the Mallarmean être de suspens, a funambule, thus following the path of lyricism, one which, according to French contemporary poet Jean-Michel Maulpoix, goes "strictly speaking, nowhere, but all along which the walker is well aware of his own weight and vertigo" (Maulpoix 9-10).

\section{BIBLIOGRAPHY}

AGAMBEN, Giorgio. Idea Of Prose. 1985. Translated from the Italian by Michael Sullivan and Sam Whitsitt. Albany: State University of New York Press, 1995.

BARTHES, Roland. A Lover's Discourse, Fragments.1978. Translated from the French by Richard Howard. London: Vintage Books, 2002.

CHIASSON, Dan. "View from the Mountain, New poems by Louise Glück." The New Yorker, 13 October 2014. www.newyorker.com/magazine/2014/10/20/view-mountain. Accessed 12 February 2021.

CAMPION, Peter. “Acquainted With the Dark.” The New York Times, 26 September 2014. www.nytimes.com/2014/09/28/books/review/louise-glcks-faithful-and-virtuous-night.html. Accessed 12 February 2021.

CULLER, Jonathan. The Pursuit of Signs, Semiotics, Literature, Deconstruction. 1981. London: Routledge, 2001.

CULLER, Jonathan. “Why Lyric?” PMLA, vol. 123, no. 1, 2008, p. 201-206.

CULLER, Jonathan. Theory of the Lyric. Cambridge: Harvard University Press, 2015.

GENETTE, Gérard. The Architext, An Introduction. 1979. Translated from the French by Jane E. Lewin. Berkeley: University of California Press, 1992.

GLÜCK, Louise. Faithful And Virtuous Night. New York: Farrar, Straus and Giroux, 2014.

GLÜCK, Louise. "Story Tellers.” American Originality. New York: Farrar, Straus and Giroux, 2017, p. 41-54. First published in American Poetry Review, vol. 26, no. 4. July/August 1997. 
HASS, Robert. A Little Book on Form, An Exploration Into The Formal Imagination Of Poetry, New York: HarperCollins, 2017.

LACOUE-LABARTHE, Philippe. Poetry as Experience: Two Poems by Paul Celan. 1968. Translated from the French by Andrea Tarnowski, 1999.

MAULPOIX, Jean-Michel. Du lyrisme. Paris: José Corti, 2000, p. 9-10. Translated from the French by Catherine Wieder. www.maulpoix.net/lyrismea.htm. Accessed 18 Nov. 2018.

PERLOFF, Marjorie. “The Linear Fallacy.” The Georgia Review, vol. 35, no. 4, The Place of Poetry: A Symposium, 1981, p. 855-869.

\section{NOTES}

1. This definition comes in opposition with what Robert Hass also says of the etymology of the word "prose": "the word comes from the Latin prosus, which means "straightforward," and is also derived from provertere, which means "to turn forward". Pro + versus, so it is distantly related to the etymological root of "verse." Prose turns forward. Verse turns" (Hass 385).

2. In The Architext Genette reminds us of Plato's notion that to him, "every poem is a narrative (diègèsis) of past, present, or future events; narrative in its broad sense can take three forms: it can be purely narrative (haplè diègèsis), it can be mimetic (dia mimèséôs-in other words, as in the theater, by way of dialogue between the characters), or it can be "mixed" (in other words, in reality alternating-sometimes narrative and sometimes dialogue, as in Homer)" (Genette 8).

3. Louise Glück's mother died when she wrote Faithful and Virtuous Night.

4. In these lines, the speaker is referring to her parents and infant sister who died, and whom she sees as in a dream.

5. This is actually Roland Barthes rephrasing Freud in Camera Lucida (Barthes 1980, 40) via JeanFrançois Chevrier, «Une inquiétante étrangeté » (with Jean Thibaudeau), in Le Nouvel Observateur, special photo issue $\mathrm{n}^{\circ} 3$, June 1978.

6. In the essay "The Linear Fallacy" Marjorie Perloff argues that "lineation, many contemporary poets and their critics seem to be saying, spells elevation. And unfortunately, such naïve faith in what Bursk rightly calls a technical gadget has produced a tolerance among us for various kinds of imprecise and sloppy writing that, were it not for their linear frame, would hardly make it past the copy editor of Newsweek, not to mention The New Yorker." (Perloff 861)

\section{ABSTRACTS}

In Louise Glück's latest collection Faithful And Virtuous Night (2014), the poet's swerving toward a more narrative form contributes-surprisingly perhaps-to revising the traditional Romantic chiasmus that exists between the mourning or suffering personae and their environment. This article attempts at capturing how Glück's choices in lineation in her verse expose the intrinsic loss and hiatus there is between language and the world. It means to illustrate the way time and lyric subjectivity are structured in Glück's latest collection. 
Dans son dernier recueil, Faithful and Virtuous Night (2014), Louise Glück fait le choix d'une forme plus narrative qui - étonnamment peut-être - contribue à la réécriture du traditionnel chiasme romantique entre les personae du recueil, sombres et en deuil, et leur environnement. Les sillons que creusent ses vers exposent la perte et le hiatus existant entre le monde et le langage. Paradoxalement, la forme poétique, plus longue et expansive, souligne l'intransitivité essentielle et caractéristique de l'écriture de Glück. Cet article entend illustrer comment le temps et la subjectivité lyrique structurent la poétique de ce recueil.

\section{INDEX}

Mots-clés: Louise Glück, Faithful And Virtuous Night, enjambement, narration, vers libre, chiasme

Keywords: Louise Glück, Faithful And Virtuous Night, enjambment, narrative, free verse, chiasmus

\section{AUTHOR}

\section{MARIE OLIVIER}

Université Paris-Est Créteil, IMAGER EA 3958 